Reprod. Nutr. Dévelop., 1987, 27 (2 B), 525-532.

\title{
Secretory profiles and production rate of growth hormone in ruminant lambs
}

\author{
M. P. LAURENTIE, M. DUClos $(*)$, P. L. TOUTAIN, J. CHARRIER $(*)$, \\ Monique BLANCHARD $\left({ }^{*}\right)$, J. P. DULOR $\left({ }^{*}\right)$, P. G. MARNET, \\ B. BARENTON $\left(^{*}\right)$
}

I.N.R.A., Station de Pharmacologie-Toxicologie, 180, chemin de Tournefeuille, 31300 Toulouse, France.

(*) I.N.R.A.-E.N.S.A., Station de Physiologie Animale, 34060 Montpellier Cedex.

Summary. Secretory profiles and production rates of growth hormone (GH) were determined in 6 ruminant lambs during winter. The mean $\mathrm{GH}$ concentrations $(3.78 \pm 2.17 \mathrm{ng} / \mathrm{ml})$ calculated were based upon blood sampling obtained every $3 \mathrm{~min}$ using a withdrawal pump. Body clearance $(0.162 \pm 0.0311 / \mathrm{h} / \mathrm{kg})$ was calculated from bolus intravenous oGH administration. The data were analysed by non-linear regression analysis ; a bicompartmental model was selected to describe the data. Production rate was $14.6 \pm 7.98 \mu \mathrm{g} / \mathrm{kg} / 24 \mathrm{~h}$. It has been emphasized that the experimental design used gave an accurate estimate of $\mathrm{GH}$ production rate.

\section{Introduction.}

Production rates of growth hormone $(\mathrm{GH})$ have been evaluated in several species, including ruminants (Yousef et al., 1969 ; Wallace et al., 1972, 1973 ; Trenkle, 1971, 1976, 1977 ; Gopinath and Kitts, 1984). Accurate evaluation of 24hour $\mathrm{GH}$ production requires a valid estimate of two parameters, body clearance $\left(\mathrm{Cl}_{\mathrm{B}}\right)$ and mean plasma concentration. The experimental design and mathematical treatment of data to estimate clearance have been well established (Tait and Burnstein, 1964 ; Gibaldi and Perrier, 1975). Nevertheless, a review of the literature indicates some inconsistencies in the calculation of $\mathrm{GH}$ clearance, especially when single administration and compartmental analysis are used. Some of the most frequent errors are the confusion between distribution and elimination processes, an excessively limited number of data points, and the inappropriate use of linear regression to fit data to a non-linear equation. The correct evaluation of mean $\mathrm{GH}$ concentration also merits attention. The episodic nature of $\mathrm{GH}$ secretion has been identified in different species including sheep (Davis and Borger, 1974 ; Davis et al., 1977). In addition, relationships between other physiological events and $\mathrm{GH}$ secretion have been established. A close association has been demonstrated between the occurrence of the first episode of slow-ware sleep and the highest peak of plasma $\mathrm{GH}$ concentration in man (Rubin et al., 1974 ; Weitzman 1976). Consequently, correct overall evaluation of mean plasma $\mathrm{GH}$ concentrations for a 24-hour period cannot be carried out on a few samples 
obtained just before $\mathrm{GH}$ administration; this evaluation requires a sampling design which will quantify plasma concentrations throughout the period under study.

The aim of the present work was to evaluate the production rate of $\mathrm{GH}$ in ruminant lambs.

\section{Material and methods.}

Six ruminant lambs ( 2 males and 4 females) of the Merinos d'Arles breed were used. They were 4 to 5 months old and weighed $30.8 \pm 2.99 \mathrm{~kg}$ on the day of continuous sampling. One month before bleeding, the lambs were put in individual cages in the same room and allowed to adapt to the experimental conditions. They were fed with hay ad libitum and received about $400 \mathrm{~g}$ of highenergy pelleted ration in a single meal at 7:30 a.m. Clean tap water was provided ad libitum. Natural photoperiod (January) was respected.

Twenty-four hours before the sampling session, indwelling jugular catheters containing heparin were inserted into both jugular veins. The next day blood samples were obtained continuously using a withdrawal pump connected to one of the catheters. Every 3 min a sample of about $1 \mathrm{ml}$ was collected and kept in a fraction collector for a maximal time of $2 \mathrm{~h}$. Thereafter, the blood was centrifuged and the plasma stored at $-20^{\circ} \mathrm{C}$ until assay. In order to avoid coagulation, heparin (Heparine Roche, Neuilly, France) was injected regularly via the other catheter ; a total dose of about $100000 \mathrm{IU}$ was used during the 24-hour sampling period. The total amount of blood removed was about $450 \mathrm{ml}$, i.e. approximately $15 \%$ of the calculated blood volume. About one month later, 6 control blood samples were obtained at 10-min intervals. Ovine growth hormone (oGH) (NIH GH5, $1 \mathrm{IU} / \mathrm{mg}$ ) was then administered at a rate of $18.46 \pm 10.17 \mu \mathrm{g} / \mathrm{kg}$ via an indwelling catheter in the right jugular vein. Just before administration, oGH was dissolved in a bovine albumin solution. Blood samples $(5 \mathrm{ml})$ were obtained from an indwelling catheter previously inserted in the left jugular vein at 1, 2, 4, 8, $15,30,45,60,90 \mathrm{~min}$ and $2,3,4$, and $5 \mathrm{~h}$ after $\mathrm{oGH}$ administration. Blood samples were collected into heparinized tubes and rapidly centrifuged. Plasma was stored at $-20^{\circ} \mathrm{C}$ until assay. oGH was measured by specific radioimmunoassay using a double antibody separation method. Reagents for the oGH assay were supplied by the National Hormone and Pituitary Program (NIADDK, Bethesda), except for the second antibody (sheep/anti-rabbit gammaglobulin) which was prepared in our laboratory. Assay sensitivity was $0.5 \mathrm{ng} / \mathrm{ml}$ and intraassay variation was $5 \%$. All the samples from the same experiment were run on the same assay at the appropriate dilution.

Data from the intravenous study were subjected to both compartmental and non-compartmental analysis. Kinetic analysis was done with a desk computer (Apple II plus), using a program for non-linear regression analysis (Koeppe and Hamann, 1980). Plasma concentrations were fitted to the general polyexponential equation 1 :

$$
C p=C_{0}+\sum_{i=1}^{n} Y i e^{-\lambda i t}
$$


In equation $1 \mathrm{Cp}$ represents plasma concentration at time ti ; Co the control GH concentration; $Y_{i}$ the coefficient of the $i^{\text {th }}$ exponential term and $\lambda i$ the exponent of the $i^{\text {th }}$ exponential term. Initial estimates were obtained using the linear regression method. For non-linear regression analysis, the data points were weighted according to equation 2 :

$$
W_{i}=1 / \hat{y}_{i}^{2}
$$
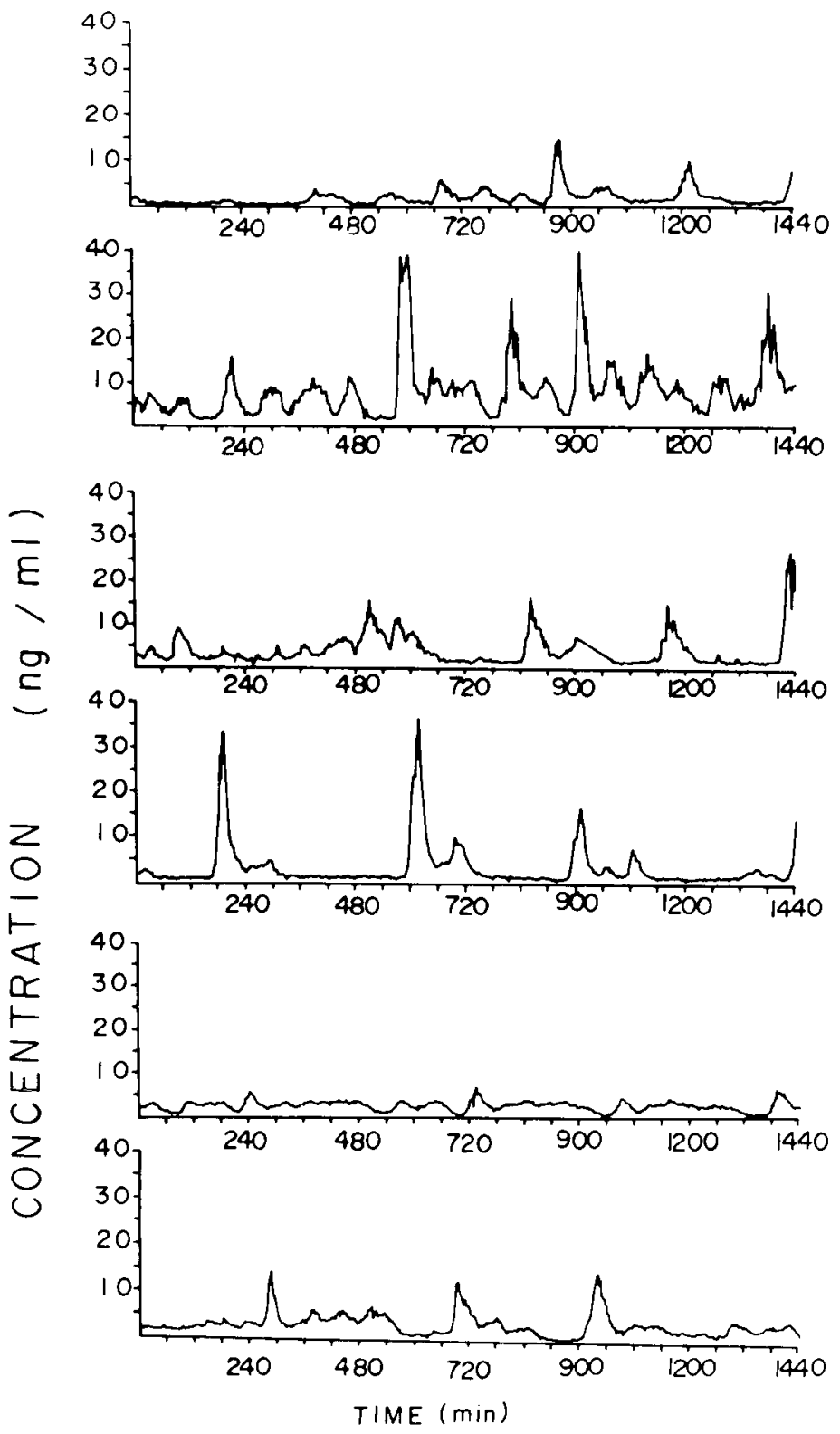

FIG. 1. - Individual 24-hour secretory profiles of $G H$ in six ruminant lambs. 
where $\mathrm{Wi}$ is the weight and $Y_{i}$ the fitted value of the $i^{\text {th }}$ observation. The number of exponents $(n)$ needed for each set of data was determined by the application of Akaike's information criterion (Yamaoka et al., 1978). The area under the plasma concentration-time curve (AUC (IV)) was calculated using the linear trapezoidal rule. Basal $\mathrm{GH}$ concentration was taken into account. The area under the plasma curve for 24-hour continuous sampling (AUC (0-24 h)) was calculated by a linear trapezoidal rule. The daily production rate of oGH (PR) was estimated by equation 3 :

$$
P R=\frac{A \cup C(0-24 h)}{A \cup C(I V)} \cdot \text { dose IV }
$$

Others parameters, such as microconstants of transfer, volume of distribution, volume of central compartment, were calculated according to classic equations (Gibaldi and Perrier, 1975). Mean residence time, i.e. the mean time needed for the intact $\mathrm{OGH}$ molecule to transit through the body (Riegelman and Collier, 1980), was calculated using a program described by Chan and Wnuck (1983).

\section{Results.}

All the sheep supported the experimental conditions and less than $3 \%$ of the samples were lost due to technical difficulties. Figure 1 shows the individual $\mathrm{GH}$ secretion profiles of the 6 lambs. Visual inspection clearly shows that $\mathrm{GH}$ secretion was not continuous but episodic. Depending on the lamb, plasma concentration fluctuated from a basal level $(0.5$ to $1 \mathrm{ng} / \mathrm{ml})$ to peak values $(8$ to $40 \mathrm{ng} / \mathrm{ml}$ ). The mean area under the plasma $\mathrm{GH}$ profile was

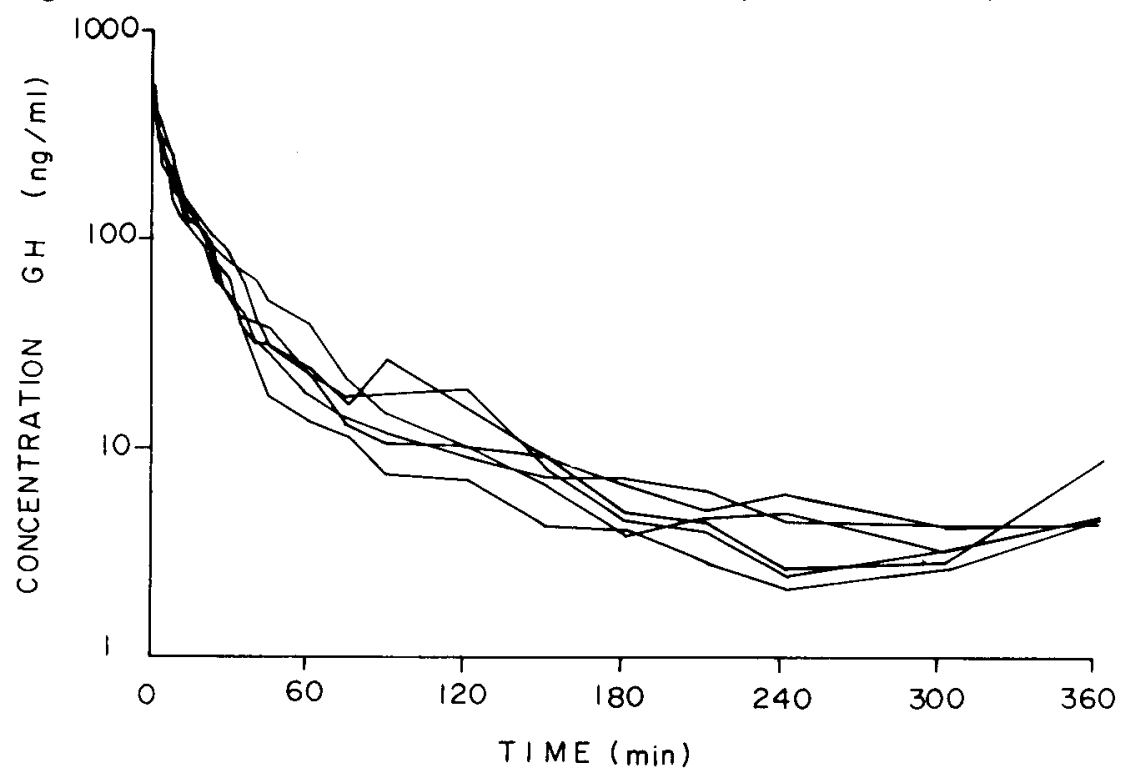

FIG. 2. - Plasma concentration of $\mathrm{GH}$ in six lambs after intravenous administration of $o G H$ at a dose of $18.46 \pm 10.17 \mu \mathrm{g} / \mathrm{kg}$. 


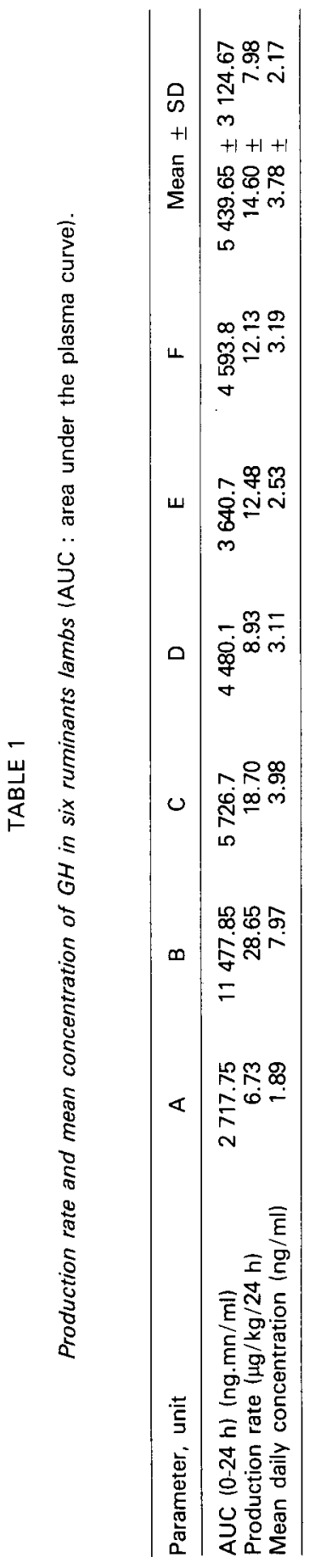


$5439 \pm 3124 \mathrm{ng} . \mathrm{min} / \mathrm{ml}$, corresponding to an overall mean concentrations of $3.78 \pm 2.17 \mathrm{ng} / \mathrm{ml}$. Individual values are presented in table 1. The plasma concentration $(\mathrm{ng} / \mathrm{ml}$ ) of $\mathrm{GH}$ after intravenous administration of $\mathrm{oGH}$ is shown for the 6 lambs in figure 2. According to Akaike's information criterion, a biexponential equation (eq. 4) must be selected to fit the data :

$$
C_{p}=C_{1} e^{-\lambda_{1} t}+C_{2} e^{-\lambda_{2} t} \text {. }
$$

Consequently, a 2-open compartment model with elimination form the central comportment can be used to described the disappearance of $\mathrm{GH}$ from the plasma. Individual parameters for the 6 lambs are expressed in table 2 ; the mean elimination half-time $(\mathrm{t} 1 / 2 \lambda 2$, i.e. $0.693 / \lambda 2$ ) was $43.50 \pm 11.15 \mathrm{~min}$ (harmonic mean and SD) and body clearance $\left(\mathrm{Cl}_{\mathrm{B}}=\operatorname{dose} / \mathrm{AUC}\right.$ (IV)) was $0.162 \pm 0.03 \mathrm{l} / \mathrm{h} / \mathrm{kg}$. According to non-compartmental analysis, mean residence time was $36.46 \pm 7.09 \mathrm{~min}$. Daily production was $14.60 \pm 7.98 \mu \mathrm{g} / \mathrm{kg}$ (range value : $6.73-28.65 \mu \mathrm{g} / \mathrm{kg}$ ). The correlation coefficient between the mean 24-hour concentration and production rate was highly significant $(r=0.95 ; P<0.01)$. In contrast, the correlation between plasma clearance and mean 24-hour concentration was not significant $(r=0.12 ; P<0.05)$.

\section{TABLE 2}

Kinetic parameters describing the disposition of $\mathrm{GH}$ after an intravenous administration of oGH in six ruminant lambs.

\begin{tabular}{|c|c|c|c|c|c|c|c|c|}
\hline \multirow{2}{*}{$\frac{\text { Parameter, unit }}{\left.Y_{1} \text { (ng } / \mathrm{ml}\right)}$} & \multirow{2}{*}{$\frac{A}{348.6}$} & \multirow{2}{*}{$\frac{B}{346.7}$} & \multirow{2}{*}{$\frac{C}{356.5}$} & \multirow{2}{*}{$\frac{D}{412.5}$} & \multirow{2}{*}{$\frac{E}{321.5}$} & \multirow{2}{*}{$\frac{F}{395.3}$} & \multicolumn{2}{|c|}{ Mean $\pm S D$} \\
\hline & & & & & & & 363.5 & \pm 33.85 \\
\hline$Y_{2}$ (ng $\left./ \mathrm{ml}\right)$ & 110.00 & 54.24 & 22.17 & 68.82 & 18.42 & 43.83 & 52.91 & 33.80 \\
\hline$Y_{0}^{2}(\mathrm{ng} / \mathrm{ml})$ & 4.61 & 1.03 & 3.64 & 0.705 & 2.36 & 2.21 & 2.42 & $\pm \quad 1.50$ \\
\hline$\lambda_{1}(\min -1)$ & 0.119 & 0.102 & 0.0845 & 0.0974 & 0.0793 & 0.0930 & 0.0959 & $\pm \quad 0.0140$ \\
\hline$\lambda_{2}\left(\min ^{-1}\right)$ & 0.0231 & 0.0132 & 0.0124 & 0.0142 & 0.0143 & 0.0166 & 0.0156 & $\pm \quad 0.0039$ \\
\hline $\mathrm{t} / / 2, \lambda_{2}(\mathrm{mn})$ & 30.00 & 52.35 & 55.88 & 48.73 & 43.41 & 41.59 & 43.50 & $\pm 11.15^{*}$ \\
\hline MRT (mn) & 32.36 & 45.92 & 35.41 & 44.38 & 29.00 & 31.36 & 36.40 & \pm 7.09 \\
\hline $\mathrm{C} 1_{\mathrm{B}}(1 / \mathrm{h} / \mathrm{kg})$ & 0.149 & 0.150 & 0.196 & 0.120 & 0.205 & 0.158 & 0.162 & \pm 0.0310 \\
\hline$V d_{\text {(area) }} 1 / \mathrm{kg}$ & 0.179 & 0.180 & 0.24 & 0.135 & 0.227 & 0.410 & 0.23 & \pm 0.097 \\
\hline $\mathrm{K}_{10}\left(\min ^{-1}\right)$ & 0.596 & 0.0534 & 0.0631 & 0.0531 & 0.0636 & 0.0638 & 0.0594 & \pm 0.0050 \\
\hline$V_{c}(1 / \mathrm{kg})$ & 0.0428 & 0.0439 & 0.0533 & 0.0399 & 0.0533 & 0.0410 & 0.0457 & \pm 0.0060 \\
\hline
\end{tabular}

$Y_{1}$ and $Y_{2}$ are preexponential constants and $\lambda_{1}$ and $\lambda_{2}$ are the exponential constants for the biexponential equation describing the plasma level curve ; $C_{0}$ is the basal control concentration time; tl/2 $\lambda_{2}$ is the plasma half-time; MRT : mean residence time; $\mathrm{Cl}_{\mathrm{B}}$ : body clearance ; Vd (area) : volume of distribution: $\mathrm{K}_{10}$ : first order rate constant of elimination from the central compartment ; $V_{c}$ : volume of the central compartment ; * harmonic mean.

\section{Discussion.}

The daily production rate of $\mathrm{GH}(15 \mu \mathrm{g} / \mathrm{kg})$ calculated for ruminant lambs in the present experiment is difficult to compare with previously published values for ruminants. Indeed, this is the first estimate of GH production taking into account the entire 24-hour GH profile. In newborn lambs, body clearance was evaluated as 
$0.18 \mathrm{l} / \mathrm{kg} / \mathrm{h}$, a value very close to that found in our ruminant lambs, and daily production rate was estimated as about $34 \mu \mathrm{g} / \mathrm{kg}$ (Wallace et al., 1973). A higher clearance has been calculated by Trenkle (1976) in fed adult sheep $(0.3731 / \mathrm{kg} / \mathrm{h})$ but the daily production rate of $19 \mu \mathrm{g} / \mathrm{kg}$, based on the measurement of basal concentration obtained before $\mathrm{GH}$ administration, was close to our estimate. In this respect it must be noted that, considering the basal levels of plasma $\mathrm{GH}$ evaluated immediately before the clearance study (6 samples at 10 -min intervals), our estimate of daily production should be significantly lower than the true value $(9.8 \pm 6.24 \mu \mathrm{g} / \mathrm{kg}$ vs $14.6 \pm 7.98 \mu \mathrm{g} / \mathrm{kg})$. A lower daily production rate $(4 \mu \mathrm{g} / \mathrm{kg})$ has been calculated in adult sheep by Wallace et al. (1972). This is due to both a low clearance value $(0.081 / \mathrm{kg} / \mathrm{h})$ and a low basal $\mathrm{GH}$ concentration (2 $\mathrm{ng} / \mathrm{ml}$ ).

In our experimental conditions, production rate was highly correlated with mean plasma concentration but not with clearance. This suggests that plasma concentrations are indicative of secretion rate and that plasma concentration differences must be explained in terms of pituitary activity rather than in terms of GH metabolism. Such a conclusion has been drawn by Trenkle (1971) studying cattle. One of the prerequistes for accurate estimation of $\mathrm{GH}$ production rate is the similarity between endogenous $\mathrm{GH}$ and that administered to evaluate clearance. Different molecular forms of $\mathrm{GH}$ have been demonstrated in man, the 22 000-dalton form being the dominant one secreted during a secretion episode, while $\mathrm{GH}$ fragments may become the dominant proportion of total immunoreactivity under basal conditions (Baumann et al., 1985a). As body clearance varies greatly among different $\mathrm{GH}$ forms (Baumann et al., 1985b), the validity of the current evaluation of the $\mathrm{GH}$ production rate in man must be questioned. Similar information is lacking in sheep.

In conclusion, if the $\mathrm{OGH}$ administered is metabolically equivalent to spontaneously secreted $\mathrm{GH}$, the present estimate of $\mathrm{GH}$ production rate for ruminant lambs in winter can be considered as accurate.

12e Réunion du groupe Développement I.N.R.A. Montpellier, 28-30 mai 1986.

Résumé. Profil de sécrétion et taux de production de l'hormone de croissance chez l'agneau ruminant.

Les profils de sécrétion et les taux de production de l'hormone de croissance (GH) ont été établis chez 6 agneaux ruminants pendant la période d'hiver. Les concentrations moyennes de $\mathrm{GH}(3,78 \pm 2,17 \mathrm{ng} / \mathrm{ml})$ ont été calculées à partir de prélèvements sanguins effectués automatiquement toutes les 3 minutes. La clairance corporelle de la $\mathrm{GH}(0,162 \pm 0,03 \mathrm{I} / \mathrm{h} / \mathrm{kg})$ a été évaluée par une administration intraveineuse d'oGH. L'analyse des données a été réalisée par régression non linéaire, un modèle bicompartimental ayant été sélectionné pour décrire les données. Le taux de production calculé est de $14,6 \pm 7,98 \mu \mathrm{g} / \mathrm{kg} / 24 \mathrm{~h}$. L'importance du protocole expérimental retenu dans l'estimation correcte du taux de production de la $\mathrm{GH}$ est discutée. 


\section{References}

BAUMANN G., STOLAR M. W., BUCHANAN T. A., 1985a. Slow metabolic clearance rate of the 20000 dalton variant of human growth hormone: implications for biological activity. Endocrinology, 117, 1309-1313.

BAUMANN G., STOLAR M. W., AMBURN K., 1985b. Molecular forms of circulating growth hormone during spontaneous secretory episodes and in the basal state. J. clin. Endocrinol. Metabol., 60, 1216-1220.

CHAN K. K. H., WNUCK K., 1983. Microcomputer-based pharmacokinetic programs for calculating absorption rate. Comput. Programs Biomed., 16, 27-34.

DAVIS S. L., BORGER M. L., 1974. Dynamic changes in plasma prolactin luteinizing hormone and growth hormone in ovariectomized ewes. J. anim. Sci., 38, 795-801.

DAVIS S. L., OHLSON D. L., KLINDT J., ANFINSON M. S., 1977. Episodic growth hormone secretory patterns in sheep : relationship to gonadal steroid hormones. $\mathrm{Am}$. J. Physiol., 233, 519-523.

GIBALDI M., PERRIER D., 1975. Pharmacokinetics. In SWARBRICK J. Drugs and the pharmaceutical sciences. Marcel Dekker, New York, 1 vol.

GOPINATH R., KITTS W. D., 1984. Growth hormone secretion and clearance rate in growing beef steers implanted with estrogenic anabolic compounds. Growth, 48, 499-514.

KOEPPE P., HAMANN C., 1980. A program for non-linear regression analysis to be used on desktop computers. Comp. Programs Biomed., 12, 121-128.

RIEGELMAN S., COLLIER P., 1980. The application of statistical moment thoery to the evaluation of in vivo dissolution time and absorption time. J. Pharmacokinet. Biopharm., 8, 509-534.

RUBIN R. T., POLAND R. E., RUBIN L. E., GOUIN P. R., 1974. The neuroendocrinology of human sleep. Life Sci., 14, 1041-1052.

TAIT J. F., BURNSTEIN S., 1964. In vivo studies of steroid dynamic in man. In G. PINCUS and K. V. THIMANN. Hormones, vol. V, 441-450. Acad. Press, NY.

TRENKLE A., 1971. Growth hormone secretion rate in cattle. J. anim. Sci., 32, 115-118.

TRENKLE A., 1976. Estimates of the kinetic parameters of growth hormone metabolism in fed and fasted calves and sheep. J. anim. Sci., 43, 1035-1043.

TRENKLE A., 1977. Changes in growth hormone status related to body weight of growing cattle. Growth, 41, 241-247.

WALLACE A. L. C., STACY B. D., THORBURN G. D., 1972. The fate of radioidinated sheepgrowth hormone in intact and nephrectomized sheep. Pflügers Arch., 331, 25-37.

WALLACE A. L. C., STACY B. D., THORBURN G. D., 1973. Regulation of growth hormone secretion in the ovine foetus. J. Endocr., 58, 89-95.

WEITZMAN E. D., 1976. Circadian rhythms and episodes hormone secretion in man. CREGER W. P., COGgINS C. H., HANCOCK E. W., Inc. Ann. Rev. Med., 27, 225-242.

YAMAOKA K., NAKAGAWA T., UNO T., 1978. Application of Akaike's information criterion (AIC) in the evaluation of linear pharmacokinetic equations. J. Pharmacokinet. Biopharm., 6, 165175.

YOUSEF M. K., TAKAHASHI Y., ROBERTSON W. D., MACHLIN L. J., JOHNSON H. D., 1969. Estimation of growth hormone secretion rate in cattle. J. anim. Sci., 29, 341-344. 